NASA/TM-2011-216752

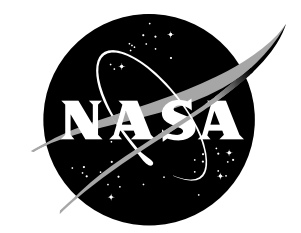

Experimental Tests of UltraFlex Array Designs in Low Earth Orbital and Geosynchronous Charging Environments

Joel T. Galofaro and Boris V. Vayner

Glenn Research Center, Cleveland, Ohio

Grover B. Hillard

Ohio Aerospace Institute, Brook Park, Ohio 


\section{NASA STI Program . . . in Profile}

Since its founding, NASA has been dedicated to the advancement of aeronautics and space science. The NASA Scientific and Technical Information (STI) program plays a key part in helping NASA maintain this important role.

The NASA STI Program operates under the auspices of the Agency Chief Information Officer. It collects, organizes, provides for archiving, and disseminates NASA's STI. The NASA STI program provides access to the NASA Aeronautics and Space Database and its public interface, the NASA Technical Reports Server, thus providing one of the largest collections of aeronautical and space science STI in the world. Results are published in both non-NASA channels and by NASA in the NASA STI Report Series, which includes the following report types:

- TECHNICAL PUBLICATION. Reports of completed research or a major significant phase of research that present the results of NASA programs and include extensive data or theoretical analysis. Includes compilations of significant scientific and technical data and information deemed to be of continuing reference value. NASA counterpart of peer-reviewed formal professional papers but has less stringent limitations on manuscript length and extent of graphic presentations.

- TECHNICAL MEMORANDUM. Scientific and technical findings that are preliminary or of specialized interest, e.g., quick release reports, working papers, and bibliographies that contain minimal annotation. Does not contain extensive analysis.

- CONTRACTOR REPORT. Scientific and technical findings by NASA-sponsored contractors and grantees.
- CONFERENCE PUBLICATION. Collected papers from scientific and technical conferences, symposia, seminars, or other meetings sponsored or cosponsored by NASA.

- SPECIAL PUBLICATION. Scientific, technical, or historical information from NASA programs, projects, and missions, often concerned with subjects having substantial public interest.

- TECHNICAL TRANSLATION. Englishlanguage translations of foreign scientific and technical material pertinent to NASA's mission.

Specialized services also include creating custom thesauri, building customized databases, organizing and publishing research results.

For more information about the NASA STI program, see the following:

- Access the NASA STI program home page at http://www.sti.nasa.gov

- E-mail your question via the Internet to help@ sti.nasa.gov

- Fax your question to the NASA STI Help Desk at $443-757-5803$

- Telephone the NASA STI Help Desk at 443-757-5802

- Write to: NASA Center for AeroSpace Information (CASI) 7115 Standard Drive Hanover, MD 21076-1320 
NASA/TM-2011-216752

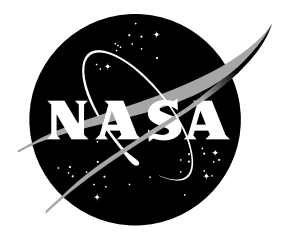

\section{Experimental Tests of UltraFlex Array Designs in Low Earth Orbital and Geosynchronous Charging Environments}

Joel T. Galofaro and Boris V. Vayner

Glenn Research Center, Cleveland, Ohio

Grover B. Hillard

Ohio Aerospace Institute, Brook Park, Ohio

Prepared for the

First Atmospheric and Space Environments Conference

sponsored by the American Institute of Aeronatuics and Astronautics

San Antonio, Texas, June 22-25, 2009

National Aeronautics and

Space Administration

Glenn Research Center

Cleveland, Ohio 44135 
Trade names and trademarks are used in this report for identification only. Their usage does not constitute an official endorsement, either expressed or implied, by the National Aeronautics and Space Administration.

Level of Review: This material has been technically reviewed by technical management.

Available from

NASA Center for Aerospace Information 7115 Standard Drive

Hanover, MD 21076-1320
National Technical Information Service 5301 Shawnee Road Alexandria, VA 22312

Available electronically at http://www.sti.nasa.gov 


\title{
Experimental Tests of UltraFlex Array Designs in Low Earth Orbital and Geosynchronous Charging Environments
}

\author{
Joel T. Galofaro and Boris V. Vayner, \\ National Aeronautics and Space Administration \\ Glenn Research Center \\ Cleveland, Ohio 44135 \\ Grover B. Hillard \\ Ohio Aerospace Institute \\ Brook Park, Ohio 44142
}

\begin{abstract}
The present ground based investigations give the first definitive look describing the expected on-orbit charging behavior of Orion UltraFlex array coupons in the Low Earth Orbital and Geosynchronous Environments. Furthermore, it is important to note that the LEO charging environment also applies to the International Space Station as well as to the lunar mission charging environments. The GEO charging environment includes the bounding case for all lunar orbital and lunar surface mission environments. The UltraFlex thin film photovoltaic array technology has been targeted to become the sole power system for life support and on-orbit power for the manned Aires Crew Exploration Vehicle. It is therefore, crucial to gain an understanding of the complex charging behavior to answer some of the basic performance and survivability issues in an attempt to ascertain that a single UltraFlex array design will be able to cope with the projected worst case LEO and GEO charging environments. Testing was limited to four array coupons, two coupons each from two different array manufactures, Emcore and Spectrolab. The layout of each array design is identical and varies only in the actual cell technology used. The individual array cells from each manufacturer have an antireflection layered coating and come in two different varieties either uncoated (only AR coating) or coated with a thin conducting ITO layer. The LEO Plasma tests revealed that all four coupons passed the arc threshold $-120 \mathrm{~V}$ bias tests. GEO electron gun charging tests revealed that only front side area of ITO coated coupons passed tests. Only the Emcore AR array passed backside Stage 2 GEO Tests.
\end{abstract}

\section{Nomenclature}

$\begin{array}{ll}E_{B} & \text { Beam energy }(\mathrm{keV}) \\ I_{D} & \text { Beam current density }\left(\mathrm{nA} / \mathrm{cm}^{2}\right) \\ N_{e} & \text { Electron number density }\left(\mathrm{cm}^{-3}\right) \\ \mathrm{R}-\mathrm{C} & \text { Resistance }(\Omega)-\text { Capacitance }(\mathrm{F}) \\ T_{e} & \text { Electron temperature }(\mathrm{eV}) \\ V_{B} & \text { Array Bias Potential, }(\mathrm{kV})\end{array}$

\section{Introduction}

The Orion arrays represent a unique design challenge in that the arrays will encounter a number of different space environments ranging from LEO to cis-lunar with passage through the Van Allen Belts, and the lunar orbital environments. Fortunately, the all cis-lunar and lunar orbital and lunar surface environments, can be effectively, categorized under a broader category termed the geosynchronous environment case. So essentially, there are only two spacecraft environments that apply: LEO and GEO. 
Traditionally, photovoltaic arrays are designed for a single environment. For the Orion mission, a single array design is needed for operation in both LEO and GEO space environments. A preliminary risk identification for CEV was made early on by the Orion Project Team (Ref. 1). The Orion Team study pointed to four major issues: (1) Atomic oxygen degradation of ITO coatings in LEO, (2) ESD breakdown of dielectric coatings in GEO during geomagnetic substorm events, (3) ESD arcing due to pinholes or damage caused by micrometeorite impacts or orbital debris, and (4) sputtering of ITO coatings and related array contamination.

LEO deployment and operations involve exposure to relatively cold dense plasma with well-known interactions issues: floating potential shifts, parasitic power loss, arcing, and atomic oxygen sputtering.

Parasitic current collection and the resulting associated power losses from the array is closely related to a highly non-linear phenomenon termed snapover (Refs. 2 and 3). Under snapover conditions a small pinhole in dielectric can collect current as much as would be the case if the entire surface were conductive. Thus, high voltage Orion array must be tested against sudden increase in current collection. The ISS Floating potential probe (FPP) measurements revealed potential spikes of $70 \mathrm{~V}$ negative (Ref. 4) that present danger of arcing on an astronaut's space suite (Refs. 5 and 6). The addition of new solar arrays to ISS and deployment of high voltage Orion solar arrays in LEO demand reevaluation of floating potential peaks and differential charging on CEV surfaces.

The GEO environment is characterized as relatively low-density plasma with high energy particles (protons and electrons) subject to violent magnetic storms (Ref. 7). As a spacecraft passes though the substorm environment, differential charging can reach a few kilovolts, which create danger of powerful electrostatic discharge. During its course to cis-lunar orbital space the Orion spacecraft will basically see three GEO space charging environments; spending approximately 73.5 percent of its time in the Solar Wind, 13.3 percent of its time in the Magneto-sheath and 13.2 percent of its time in the Magnetotail. Table 1 gives a comparison of worst case charging environments (Refs. 1 and 7). Table 1 also tabulates the worst case GEO charging (Design Case) designated for the Orion CEV spacecraft photovoltaic array surfaces. The general practice for spacecraft designers has been to use a single spacecraft design for operation in LEO and separate spacecraft design for operation in the GEO environment. As a result, the common practice of photovoltaic array manufacturer is to insulate all array cells with $\mathrm{SiO}_{2}$ cover slides for operation in LEO environment, and to force the array cell $\mathrm{SiO}_{2}$ cover slide to become conducting by over-coating the insulating cover slide with a thin layer of Indium Tin Oxide (ITO) for operation in the GEO environment. Because a single array design is required for operation in both LEO and GEO environments, the consensus made by the Orion CEV Project Team was to have ITO coating on each photovoltaic array. Since all arrays are required to have AR (MgF2) coatings, the only other specification was that the MgF2 coating be thin enough to allow charge to bleed through the AR coating, providing a surface resistance of approximately $10^{7} \mathrm{Ohm} / \mathrm{cm}^{2}$. The purpose of the current tests is to ascertain the viability of Emcore and Spectrolab array cells to satisfactorily perform ESD free under worst case LEO and GEO charging conditions.

TABLE 1.-WORST CASE GEO CHARGING ENVIRONMENTS

\begin{tabular}{|l|c|c|c|c|}
\hline & Design case & Solar wind & Magneto-sheath & Magneto-tail \\
\hline Electron density, $\mathrm{cm}^{-3}$ & 1.12 & 9.5 & 1.1 & 0.16 \\
\hline Electron temperature, $\mathrm{eV}$ & $1.2 \times 10^{4}$ & 12.1 & 26.9 & 145.6 \\
\hline Proton density, $\mathrm{cm}^{-3}$ & 0.24 & 8.7 & 1 & 0.15 \\
\hline Proton temperature, $\mathrm{eV}$ & $2.95 \times 10^{4}$ & 10.3 & 79.9 & 610.1 \\
\hline
\end{tabular}




\section{Experimental Apparatus}

All tests were conducted at the NASA Glenn Research Center's National Plasma Interaction Facility Tenney Charging Simulator VF-20 Chamber (See Fig. 1 for details). (Vacuum chamber dimensions: $1.5 \mathrm{~m}$ length and $1.8 \mathrm{~m}$ diameter.) The chamber is equipped with large $0.9 \mathrm{~m}$ diameter cryogenic pump that is provides a background pressure of $2 \times 10^{-7}$ Torr. A digital ionization gage was used to readout the chamber pressure. The chamber is equipped with a Kaufmann type discharge source that ionizes xenon gas neutrals via a hot filament cathode. The Kaufmann xenon discharge source was used to simulate the electrical charging conditions encountered in the LEO environment. Tank pressure was adjusted by slowly bleeding xenon gas neutrals into the chamber until a pressure of $5.0 \times 10^{-5}$ Torr was achieved. Plasma parameters were obtained by sweeping a Langmuir Probe $\left(N_{e}=10^{6} \mathrm{~cm}^{-3}, T_{e}=0.5 \mathrm{eV}\right)$.

For GEO testing the vacuum chamber pumped down to the base tank pressure and the array coupons were allowed to outgas in the chamber for a minimum of $8 \mathrm{hr}$ prior to testing. Two electron guns with matching $0-20 \mathrm{kV}$ accelerating power supplies provided the electron beam flux needed to sufficiently charge up the arrays to simulate the GEO environment. Both electron guns were mounted on the chamber door. A single photovoltaic array coupon was mounted at the far end of the chamber for testing. A twodimensional (2-D) tracking system was installed in front of the array. The tracking system carried an electrostatic non-contact probe for measuring potentials on the array surfaces. The 2-D tracking system also included a Faraday Cup for measuring beam current density. A digital high impedance voltmeter and respective software were used to plot and save TREK probe position and potential distribution via a laptop computer.

In principal, only the ram side of the array can be tested at a time because of wake effects caused by shadowing of the backward facing array surfaces. Therefore, the vacuum chamber needs to be re-opened and the array flipped for retesting the backside array surfaces. Array testing was limited to just four individual coupons, two each from two different cell manufactures: Emcore and Spectrolab. Emcore provided coupons with B Triple Junction Monolithic (BTJM) cell design: one AR coated (AR-BTJM) and one with an Indium Tin Oxide (AR-ITO-BTJM) coatings. The two Spectrolab coupons contained the Ultimate Triple Junction (UTJ) cells: one with an AR coating (AR-UTJ) and one with an ITO coating (AR-ITO-UTJ). Both BTJM and UTJ array designs incorporated a bypass diode in each array string to limit current in the case of sustained arcing between adjacent strings.

The layout of each of the four coupons was identical: four parallel strings with four cells per string. An insulating Vectran gore (mesh) was attached to a rigid insulating composite fiberglass $(\mathrm{G}-11)$ frame

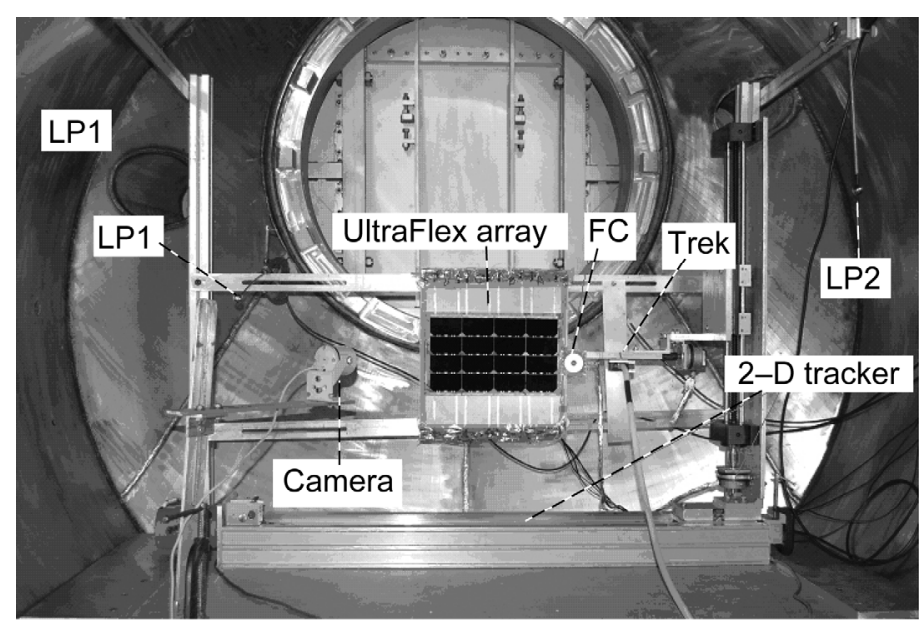

Figure 1.-Snapshot showing Tenney Charging simulator VF-20 Chamber. The UltraFlex array rigidly mounted at the far end of the chamber. 
with the cells cemented directly on the Vectran mesh. Emcore used thin conductive strips for each string output lead. The thin conductive strips are brought out to the edge of the frame and terminated via the string termination pads. All conducting strips have a thin insulating layer of Tedlar covering each conductive strip. See Figures 2(a) to 2(d) for details. The Spectrolab arrays had no such conductive strips. The Spectrolab arrays also had a thin insulating Kapton (DuPont) sheet masking off the non cell areas. The backsides of the CIC cells were left exposed.
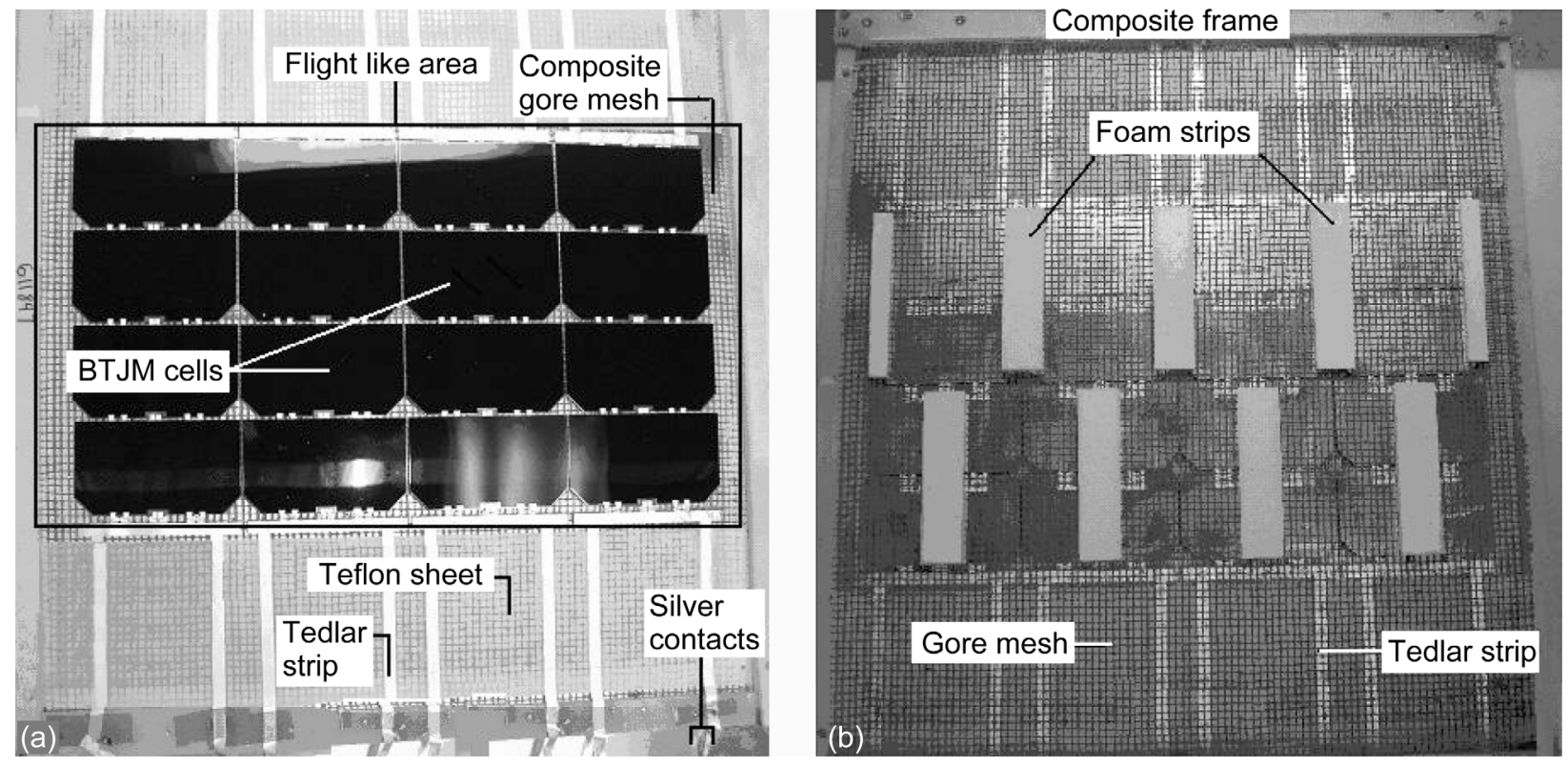

Figure 2.-(a) Front side of UltraFlex array with Emcore AR-BTJM CIC cells array. (b) Back side of the UltraFlex Emcore array. Teflon cover sheet only appears only on the front side (a).
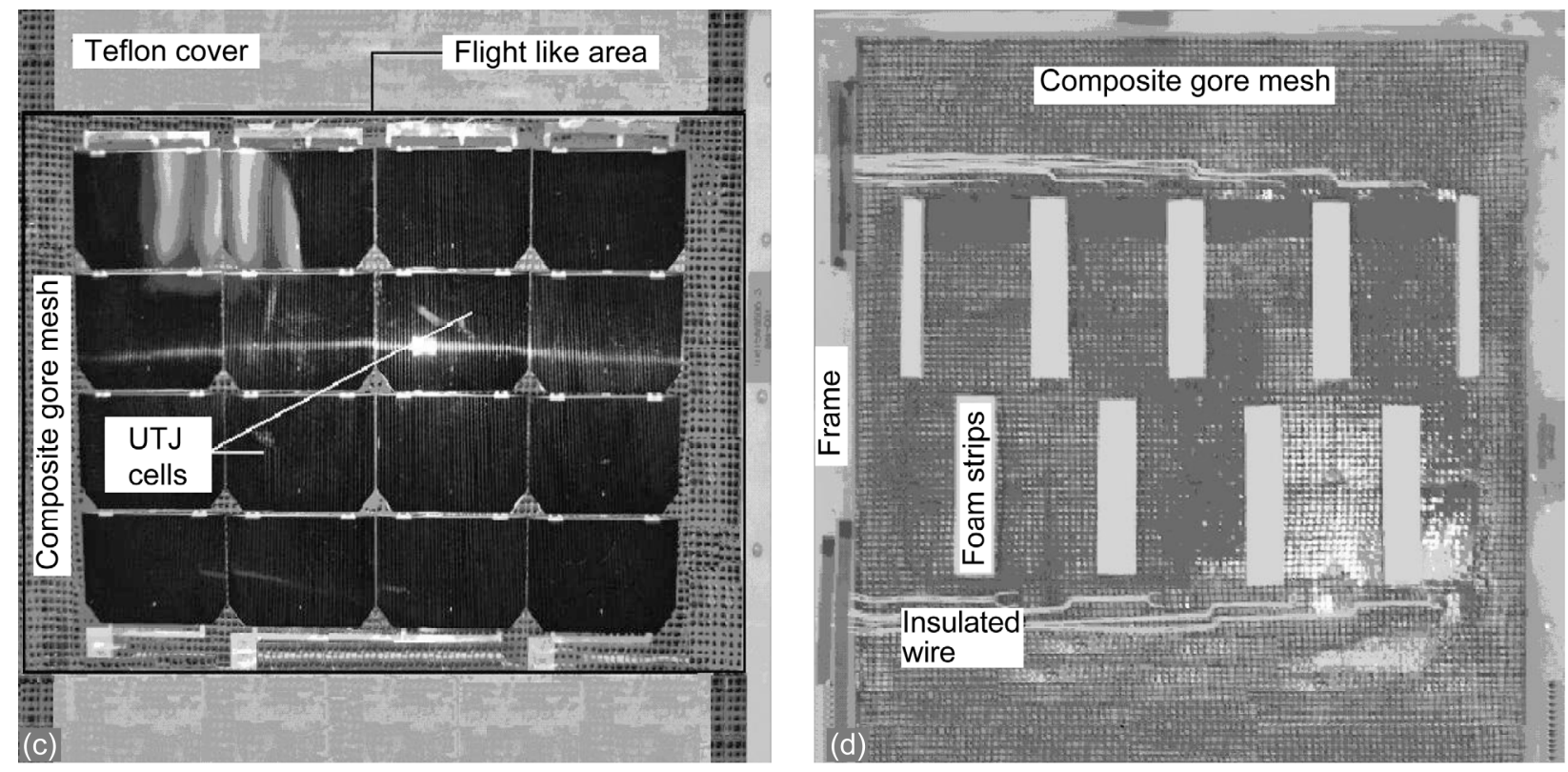

Figure 2.-(c) Front side of UltraFlex array with Spectrolab AR-UTJ CIC cells array. (d) Back side of the UltraFlex Spectrolab array. Teflon cover sheet clearly seen in Fig. $2 a$. 
The circuitry diagram for testing against ESD inception in both LEO and GEO environments is shown in Figure 3. Figure 3(a) shows an R-C circuit, current probe and current probe amplifier used to detect primary arcs on the array. When an arc occurred and exceeded a pre-programmed trigger level, the waveform data were recorded to a specified file on the computer; the scope was then switched back automatically into ready mode awaiting the next arc. If an arc occurred between two adjacent strings the setup in Figure 3(b) would be used to check for sustained arcs. A color video camera mounted inside the vacuum chamber was used for recording arcs on VCR. Additionally, a quadrupole mass spectrometer was used to monitor the gas species in the chamber during the test.

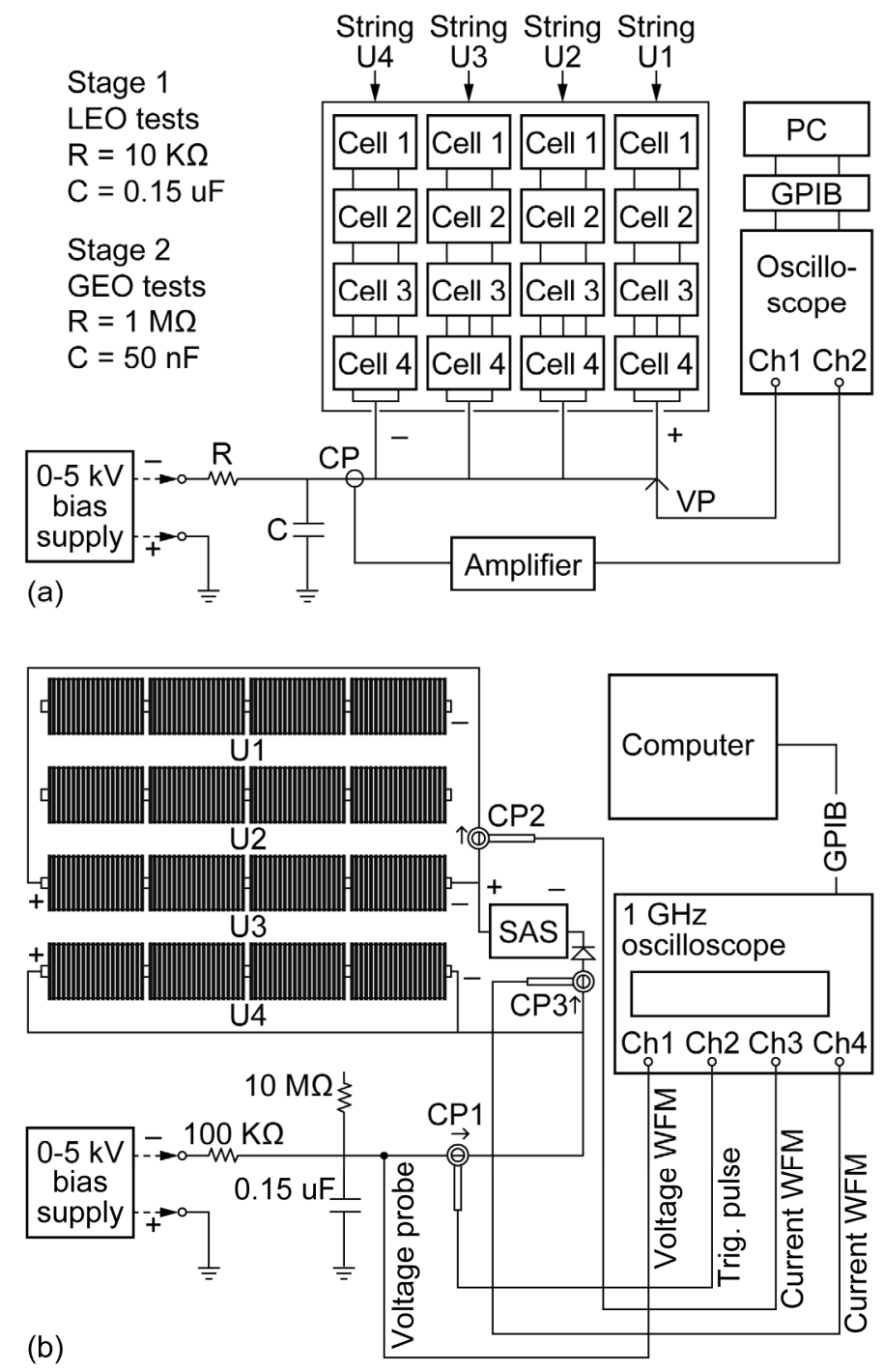

Figure 3.-(a) ESD detection circuitry diagram. (b) Experimental setup employed for sustained arc LEO test. 


\section{LEO and GEO Test Procedures}

The following test plan sequence started on delivery of each solar array sample: Photographs of the front and backside of the array were taken prior to testing followed by visual inspections to document any anomalies during shipment. Array coupons were then hand delivered to our Cell Calibration Flash Simulator Laboratory to make a baseline performance measurement at room temperature prior to ESD testing. Measurements of short circuit current, open circuit voltage, maximum voltage, maximum current, maximum power and cell efficiency were performed for each array string. The array was then hand delivered to the Atomic Oxygen Facility for a sweeping 10-day AO/UV exposure expose test of the AR (or ITO) coatings. Photographs were taken to document regions of interest that might be degraded from AO exposure. Finally, the array was hand carried to the Plasma Interaction Facility (PIF) for extensive testing in LEO and GEO environments.

\section{Stage 1-LEO Test Procedure Details}

Figure 1 shows a single Emcore coupon mounted in the chamber. The output leads of each array string were shorted together and connected to a separate high voltage electrical vacuum feed-throughs.

Parasitic current for each string was measured separately by sweeping bias voltage within the range of 0 to $120 \mathrm{~V}$. (It is worth noting that the collection current is practically proportional to number density in our range of interest because the Debye radius is much shorter than the sample dimension). The array bias step voltage was held for one second before recording the collection current measurement at each voltage step. Finally, estimates for the parasitic losses were obtained and compared with photovoltaic currentlosses were not exceeded 0.5 percent.

For the arc threshold tests the bias voltage was initially set to $-40 \mathrm{~V}$, and the array was held at this bias level for $60 \mathrm{~min}$. If no arc occurred, the bias voltage was decreased in $-10 \mathrm{~V}$ decrements, and coupon was retested for another $60 \mathrm{~min}$. The procedure was repeated down to the $-120 \mathrm{~V}$ bias voltage limit. (The arcing threshold limit of $-120 \mathrm{~V}$ was modified by the test plan committee after the end of the Emcore AR-ITO arc threshold tests. The $-120 \mathrm{~V}$ limit was replaced by a limit of $-240 \mathrm{~V}$ as a new margin of safety.) No arc was registered on all four tested samples biased up to $240 \mathrm{~V}$ negative. This result negated the necessity of testing against sustained arc inception.

\section{Stage 2-GEO Test Procedure Details}

All array strings are shorted together and connected to the negative terminal of a grounded high voltage power supply. Initially the array bias, $V_{B}$ is set for $-1 \mathrm{kV}$ and the electron gun beam energy, $E_{B}$ is set to $1.8 \mathrm{keV}$ before proceeding. The beam current densities for both electron guns are initially set to $1 \mathrm{nA} / \mathrm{cm}^{2}$ and the array sample is irradiated for $30 \mathrm{~min}$. If an arc occurs during this time span, the array fails. If no arcs are detected at the end of the 30 min irradiation test, the beam current flux density is increased to $2 \mathrm{nA} / \mathrm{cm}^{2}$ and the array is allowed to sit under irradiation for another $30 \mathrm{~min}$. All four samples underwent the GEO tests with current densities of 1, 2, and $5 \mathrm{nA} / \mathrm{cm}^{2}$, and bias voltages of 1,2 , 3 , and $5 \mathrm{kV}$.

\section{LEO and GEO Test Results}

Visual inspections of each array showed no cracks or imperfections to the CIC cells, but pointed out a number of other abnormalities: large exposed conductive strips need to be insulated, and the Vectran gore mesh needs to be under greater tension to provide a flat surface to affix cell coupons. Slight modifications were made to each array sample at the PIF Lab prior to installation in the VF-20 chamber. These modifications consisted of applications of adhesive backed Kapton tape to cover up the bus bars and exposed parts of connecting strips in order to decrease errors in the collection current measurements. Kapton tape was also added along the sides of the Vectran gore mesh not properly affixed to the frame. 
LEO string current collection was measured by biasing the strings and sweeping bias between 0 and $+120 \mathrm{~V}$ in $1 \mathrm{~V}$ steps using a sensitive sourcemeter to record the current at each voltage step. Current collection are measured for the front and backsides of each of the four UltraFlex arrays. Plotted results for the front side of the first Emcore AR-ITO coated array sample in Figure 4(a) Front and backside current collection results are plotted for the second Emcore AR coated array sample in Figure 4(b). Similar plots for the front and backside of the two Spectrolab AR-ITO coated and AR coated array samples are shown in Figures 4(c) and 4(d). Front Side current collection results for are separately plotted for all AR-ITO and AR coated array sample coupons for each of the Emcore and the Spectrolab array samples in Figures 4(e) and 4(f). It is also interesting to note that the AR-ITO coated array cells collect 1.7 to 2 times more current than cells only coated with AR coated layer. More quantitative array current collection results are conveniently summarized in Table 2 .
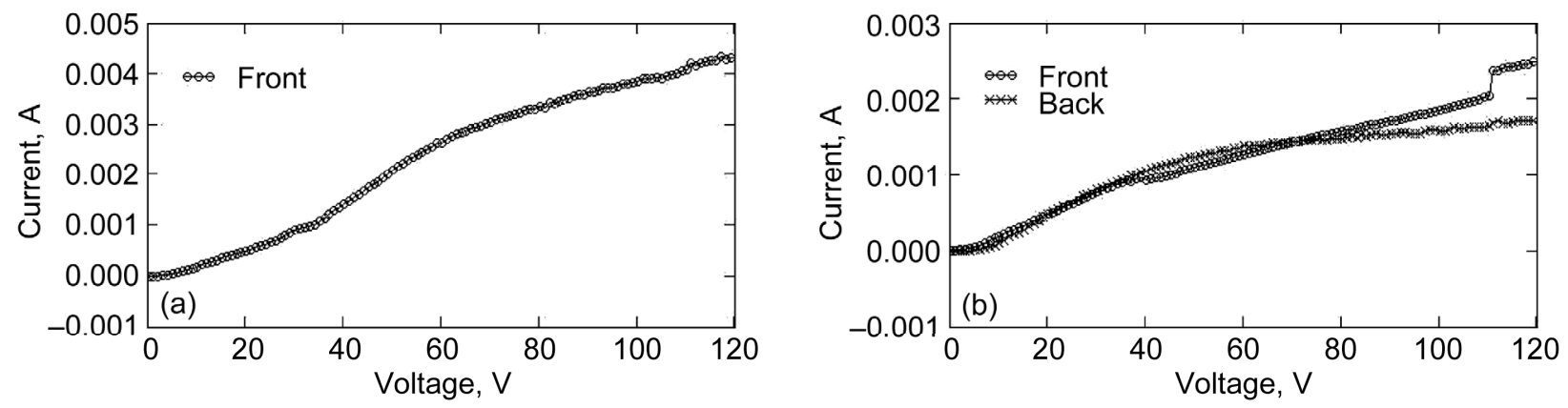

Figure 4.-Current collection for two Emcore coupons. (a) Front and backside collection cure for Emcore AR-ITO coated array. (b) Emcore AR coated array.
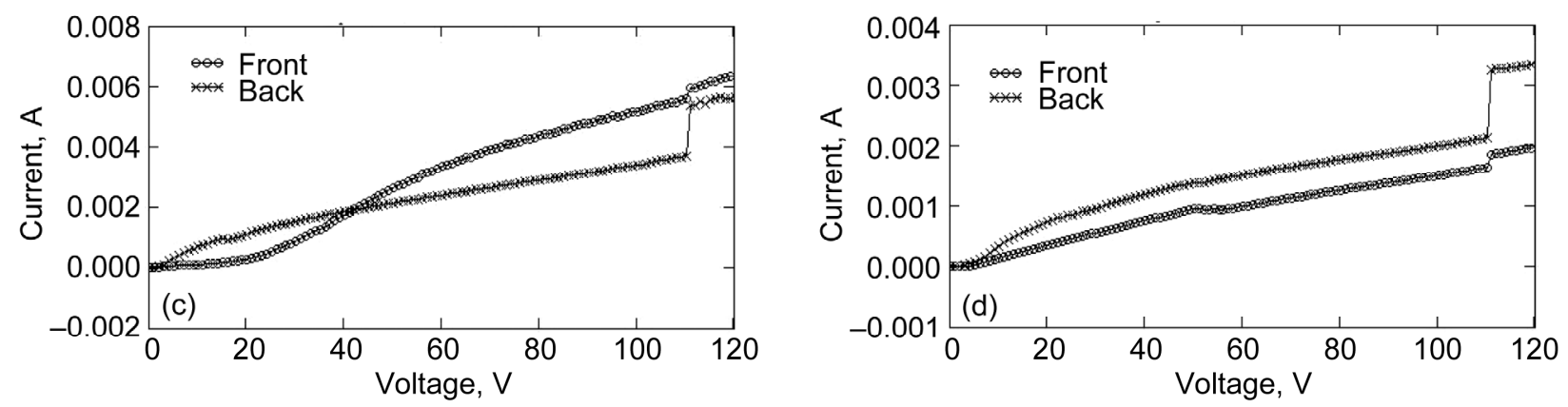

Figure 4.-Continued. Current collections are shown for two Spectrolab coupons. (c) Spectrolab ITO-AR.

(d) Spectrolab AR coated array.
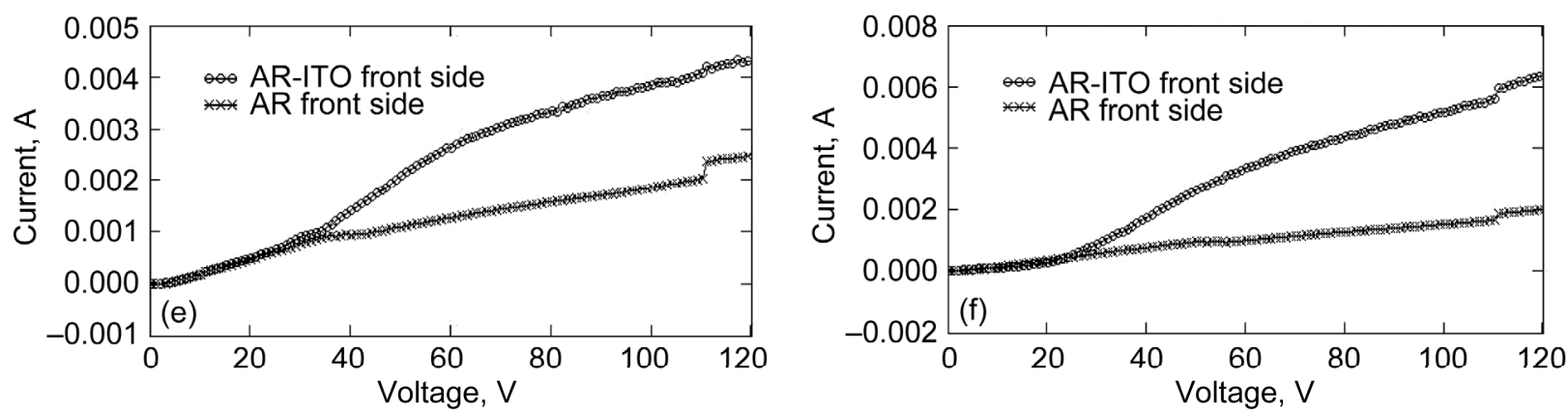

Figure 4.-Concluded. Front side of Emcore AR-ITO coated array collects 1.7 times more current at $110 \mathrm{~V}$ then the front side of the Emcore AR coated array (e). Front side of Spectrolab AR-ITO coated array collects 2 times more current at $110 \mathrm{~V}$ then the front side of the Spectrolab AR coated array (f). 
TABLE 2.-SUMMARY OF COLLECTED CURRENT RESULTS

\begin{tabular}{|l|l|c|c|l|}
\hline \multicolumn{1}{|c|}{ Coupon } & $\begin{array}{c}\text { Current collected at } \\
+10-\mathrm{V}(25 \% \text { of max } \\
\text { string Vop of 35-V), A }\end{array}$ & $\begin{array}{c}\text { Equivalent 19-cell } \\
\text { string level current } \\
\text { collection, A }\end{array}$ & $\begin{array}{c}\text { Successful } \\
\text { test? }\end{array}$ & Comments \\
\hline Emcore AR & 0.00030 front & 0.00018 & Success & $\begin{array}{l}\text { Higher collected current than AR-ITO } \\
\text { coupon indicates coupon labels may } \\
\text { have been switched. Collected current } \\
\text { difference increases to a factor } 2 \times \text { at } \\
+50 \text {-V bias. }\end{array}$ \\
\hline Emcore AR-ITO & $\begin{array}{l}0.00025 \text { front }+ \\
0.00016 \text { back } \\
0.00041 \text { total }\end{array}$ & 0.00026 & Success & \\
\hline Spectrolab AR & $\begin{array}{l}0.00020 \text { front }+ \\
0.00030 \text { back } \\
0.00050 \text { total }\end{array}$ & 0.00030 & Success & \\
\hline Spectrolab AR-ITO & $\begin{array}{l}0.00020 \text { front }+ \\
0.00075 \text { back } \\
0.00095\end{array}$ & 0.00059 & Success & $\begin{array}{l}\text { Current collected is above } 0.00040 \\
\text { amp goal but is still an acceptably } \\
\text { small value of } 0.15 \% \text { of the string } \\
\text { operating current. }\end{array}$ \\
\hline
\end{tabular}

TABLE 3.-LEO ARC THRESHOLD TEST RESULTS

\begin{tabular}{|l|c|c|c|l|}
\hline \multicolumn{1}{|c|}{ Coupon } & $\begin{array}{c}\text { Arc at most negative bias } \\
\text { required (-80-V, driven by } \\
\text { mated-ISS case) } \\
\text { Yes/no }\end{array}$ & $\begin{array}{c}\text { Arc at most } \\
\text { negative bias } \\
\text { tested? } \\
\text { Yes/no }\end{array}$ & $\begin{array}{c}\text { Successful } \\
\text { test? }\end{array}$ & Comments \\
\hline Emcore AR & No & No (to -120-V) & Success & Good margin demonstrated. \\
\hline Emcore AR-ITO & No & No (to -240-V) & Success & $\begin{array}{l}\text { Very good margin } \\
\text { demonstrated. }\end{array}$ \\
\hline Spectrolab AR & No & No (to -240-V) & Success & $\begin{array}{l}\text { Very good margin } \\
\text { demonstrated. }\end{array}$ \\
\hline Spectrolab AR-ITO & No & No (to -240-V) & Success & $\begin{array}{l}\text { Very good margin } \\
\text { demonstrated. }\end{array}$ \\
\hline
\end{tabular}

For the LEO arc threshold tests were performed in separate consecutive one hour runs at increasing negative array bias voltages ( $-10 \mathrm{~V}$ steps) down to the maximum level of $240 \mathrm{~V}$ negative. Because there were no primary arcs no test against sustained arcs occurring was needed. Final LEO arcing threshold test results are shown in Table 3.

\section{Emcore AR-ITO array GEO Results}

All four array strings were shorted together and connected to a high-voltage power supply through the $\mathrm{R}-\mathrm{C}$ circuit shown in Figure 3(a) (resistor and capacitance values in the $\mathrm{R}-\mathrm{C}$ circuit were $R=1 \mathrm{M} \Omega$, and $C=50 \mathrm{nF}$ ). A problem developed early on in the tests: a number of arcs were registered on the non-flight like areas on the front of the array sample, even at the lowest levels of charging. Discharges were registered in less than 1 min after starting array sample irradiation. Peak current reached $8 \mathrm{~A}$ with a pulse width of about $10 \mu$ s (Fig. 5). The TREK probe scan of the cell surfaces showed no signs of differential charging; thus, the ITO layer was effectively bleeding off charges. The sample was re-irradiated by 


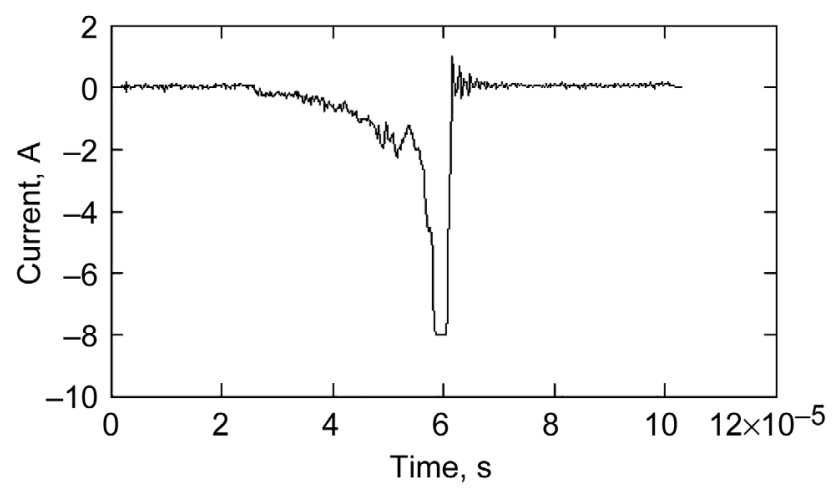

Figure 5.-Example of arc pulse on dielectric Tedlar covering conducting strip. Charging due to e-beam exposure at low beam energy of $1.1 \mathrm{keV}$ and beam current density of $1 \mathrm{nA} / \mathrm{cm}^{2}$.

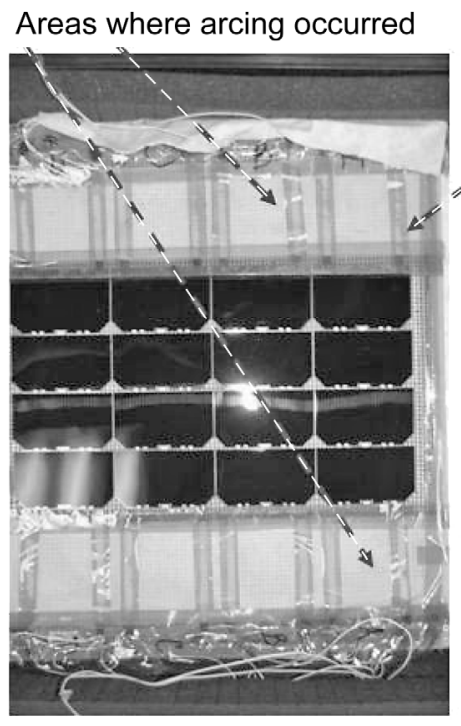

Modified coupon after arcing noted at Kapton tape overlay on beginning of GEO test Tedlar coated conducting strip

Figure 6.-Modifications made to the Emcore and Spectrolab (AR and AR-ITO) UltraFlex array samples.

energizing the EG using the same array bias potential, beam energy and current density settings, and 10 more discharges were generated. Arc sites were clearly located: arcs occurred on the exposed thin Teflon (DuPont) paper sheet and on the Tedlar (DuPont) dielectric coatings. At this point the decision was made to modify the array by covering all exposed Tedlar strips on the front of the array with Kapton tape (Fig. 6). No modifications were made to the backside of the array. These modifications allowed testing cell area only. No surface charging was found at current densities 1,2 , and $5 \mathrm{nA} / \mathrm{cm}^{2}$ and beam energy up to $3.5 \mathrm{keV}$. The array was next biased at $-2.9 \mathrm{kV}$ negative and irradiated with electron beam energy $3.5 \mathrm{keV}$ and current density of $7 \mathrm{nA} / \mathrm{cm}^{2}$. Kapton tape strips were charged and an arc discharge occurred. Sample was dismounted from the VF-20 chamber and brought to calibration laboratory. No indication of visual damage or burn marks were found on the sample. The Calibration Laboratory recorded a loss of efficiency in each of the four strings. After the sample was returned a last attempt was made at biasing the 

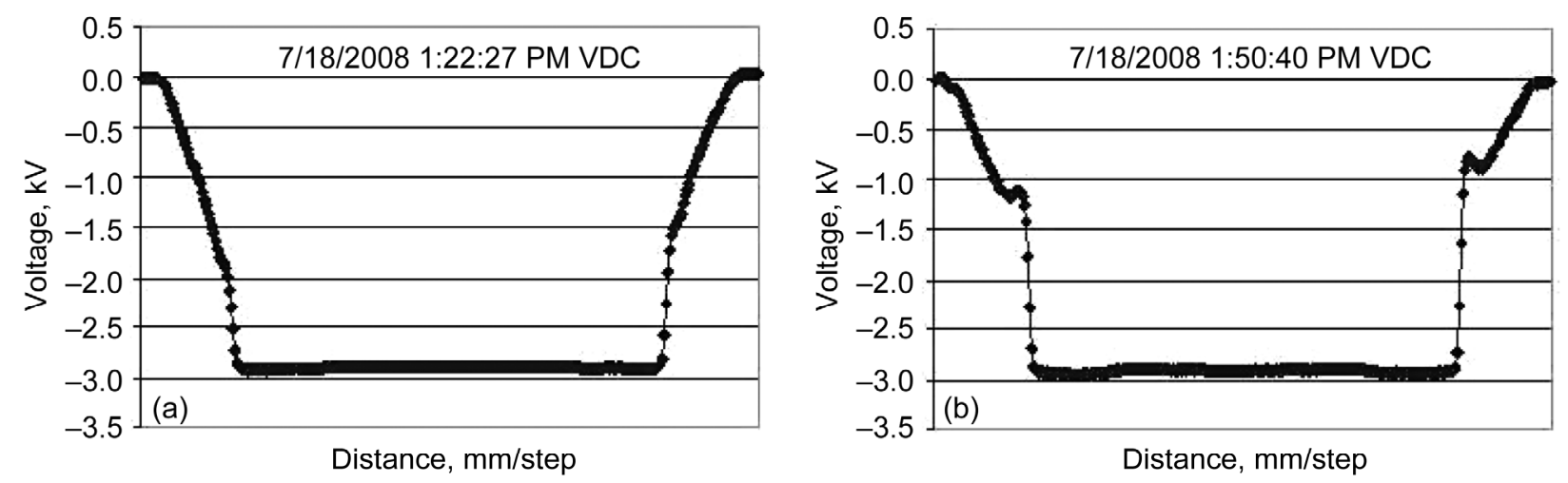

Figure 7.-(a) Electrostatic probe surface scan with array biased at $-3 \mathrm{kV}$ but not irradiated. (b) Electrostatic probe surface potential after $5 \mathrm{~min}$ irradiation at respective beam parameters of $V_{B}=-3 \mathrm{kV}, E_{B}=3.5 \mathrm{keV}$ and $I_{B}=7 \mathrm{nA} / \mathrm{cm}^{2}$. (Horizontal distance between points is $2.2 \mathrm{~mm}$ ).

array sample at $-2.9 \mathrm{kV}$ irradiating the sample with a beam energy of $3.5 \mathrm{keV}$ and beam current density of $7 \mathrm{nA} / \mathrm{cm}^{2}$ for a $5 \mathrm{~min}$ exposure. Electron gun power supply's were shut down and an electrostatic probe scan was performed directly after e-beam exposure. The electrostatic probe scan clearly demonstrated charging of Kapton tape and a complete absence of charging on any of the cell surfaces whatsoever (Fig. 7). The Emcore AR-ITO BTJM array successively passed all Stage 2-GEO tests. GEO tests were not performed on the backside of the Emcore AR-ITO array.

\section{Emcore AR GEO Results}

Initially the Emcore AR array was biased at $-1.1 \mathrm{kV}$. Note that the top cell (cell 1) on the array string U4 was cracked, while trying to remove section of Kapton tape which fell on the cell. Figure 8(a) shows an example of a surface probe scan of potentials for the Emcore AR array biased at $1.1 \mathrm{kV}$, but not irradiated. Figure 8(b) shows a surface scan of potentials after irradiation, with the array still biased at $-1.1 \mathrm{kV}$ under an e-beam using a beam energy of $1.8 \mathrm{keV}$ and with beam current density of $2 \mathrm{nA} / \mathrm{cm}^{2}$. No arcs were detected but a scan of surface potentials shows the Emcore AR coated array appears to have acquired differential charging on CIC cells of the order of $-900 \mathrm{~V}$, which clearly indicates that no ITO layer is present on the CIC coupons. Beam current density was increased to $5 \mathrm{nA} / \mathrm{cm}^{2}$ and one arc occurred on the cracked cell. String U4 was removed from the circuit. Continued irradiation at the previous beam current density showed no arcing occurred. Array bias level was increased to $-2 \mathrm{kV}$ with the beam energy was raised to $2.8 \mathrm{keV}$ and the sample was tested at beam current densities $1,2,5$, and $10 \mathrm{nA} / \mathrm{cm}^{2}$ with no arcs detected on the flight like cell surfaces. However, three arcs were triggered on the non-flight like array, first two arcs occurred on the Teflon sheet and the third arc was detected on the Kapton covered Tedlar strip. Resumed testing with the array biased at $-3 \mathrm{kV}$, beam energy $3.5 \mathrm{keV}$ and a beam current density of 2,3 , and $5 \mathrm{nA} / \mathrm{cm}^{2}$ with no arcs detected on the flight like areas of the Emcore AR array. Beam current density was increased to $10 \mathrm{nA} / \mathrm{cm}^{2}$ and a discharge occurred in the area covered by Kapton tape after 10 min of irradiation (Fig. 9). The chamber was opened and additional Kapton covers were added to areas of the composite frame and connecting strips. Array sample bias was increased to $-3 \mathrm{kV}$ and irradiated with a beam energy of $3.5 \mathrm{keV}$ with a current density of $2 \mathrm{nA} / \mathrm{cm}^{2}$. The first arc occurred on the string U2 interconnect between cells 3 and 4. A probe scan of surface potentials indicated differential charging up to $1.5 \mathrm{kV}$. Beam current density was increased to $3 \mathrm{nA} / \mathrm{cm}^{2}$ and another arc occurred on the interconnect between cells 3 and 4 on string U1. Beam current was increased to $5 \mathrm{nA} / \mathrm{cm}^{2}$ and an arc occurred between cell 3 on string U1 and cell 3 on string U2. A final arc was detected about 15 min later on string U3 between cells 2 and 3. Therefore, the front side of the Emcore AR array failed to pass Stage 2 GEO tests due to arcing on the flight like areas of the array. 

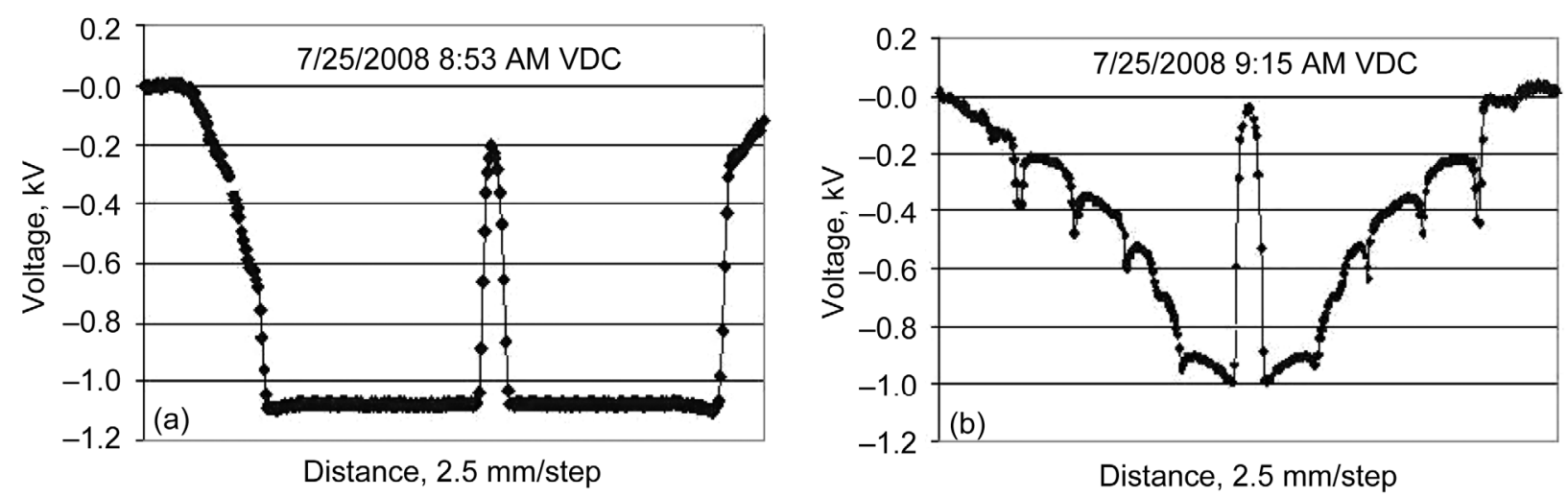

Figure 8.-(a) Probe scan of Emcore-AR coupon indicated a potential of $-1.1( \pm 0.05) \mathrm{kV}$ before irradiation.

(b) Differential potential of about $900 \mathrm{~V}$ after irradiation.

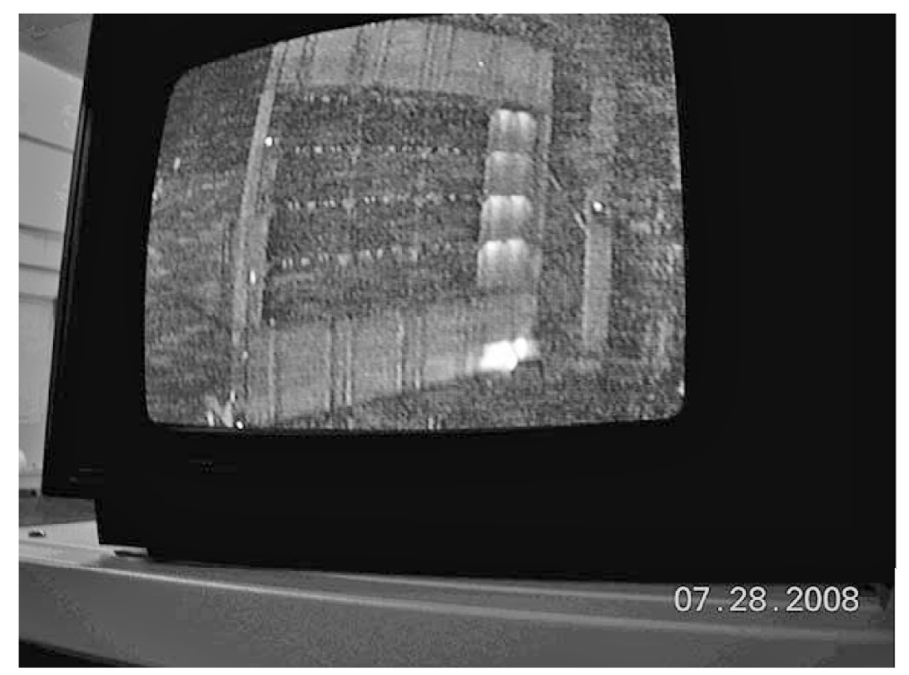

Figure 9.-Discharge on Teflon covered area at $-2 \mathrm{kV}$ bias voltage with beam energy at $2.8 \mathrm{keV}$ and with a beam current density of $10 \mathrm{nA} / \mathrm{cm}^{2}$. Note: four lighted cells above arc site are due to reflections from the primary arc.

The chamber was opened and the backside of the Emcore AR coated array was reinstalled with the electron guns pointed directly at the backside of the array. Backside testing started the $-2 \mathrm{kV}$ array bias. No arcs were detected in a 17 min test under irradiation with beam energy of $2.8 \mathrm{keV}$ and beam current density of $5 \mathrm{nA} / \mathrm{cm}^{2}$. Bias level of the array was increased to $-3 \mathrm{kV}$ with beam energy set to $3.5 \mathrm{keV}$ and a beam current density of $1 \mathrm{nA} / \mathrm{cm}^{2}$. One arc occurred near the top left side of the Kapton cover. Two more arcs were detected on the backside of the array in the area on the conducting strip near the edge of the composite frame. Array bias voltage was increased to $-5 \mathrm{kV}$ and the backside of the array was irradiated with e-beam energies of $5.7 \mathrm{keV}$ with a current density of $5 \mathrm{nA} / \mathrm{cm}^{2}$. Three more arcs were recorded: one arc occurred near the top middle region of the array on the Kapton cover applied over the composite frame and the other two arcs on the Vectran gore mesh near to the string conducting strips. A final attempt was made to see the effects of charging the backside of the array at extreme GEO levels. For this test the array sample was biased at $9.5 \mathrm{kV}$ and the backside of the array was irradiated with a beam energy of $10 \mathrm{keV}$ and a current density of $10 \mathrm{nA} / \mathrm{cm}^{2}$. This extreme charging test resulted in multiple number of very intensive arc discharges scattered over face of the backside of the array (Fig. 10). 


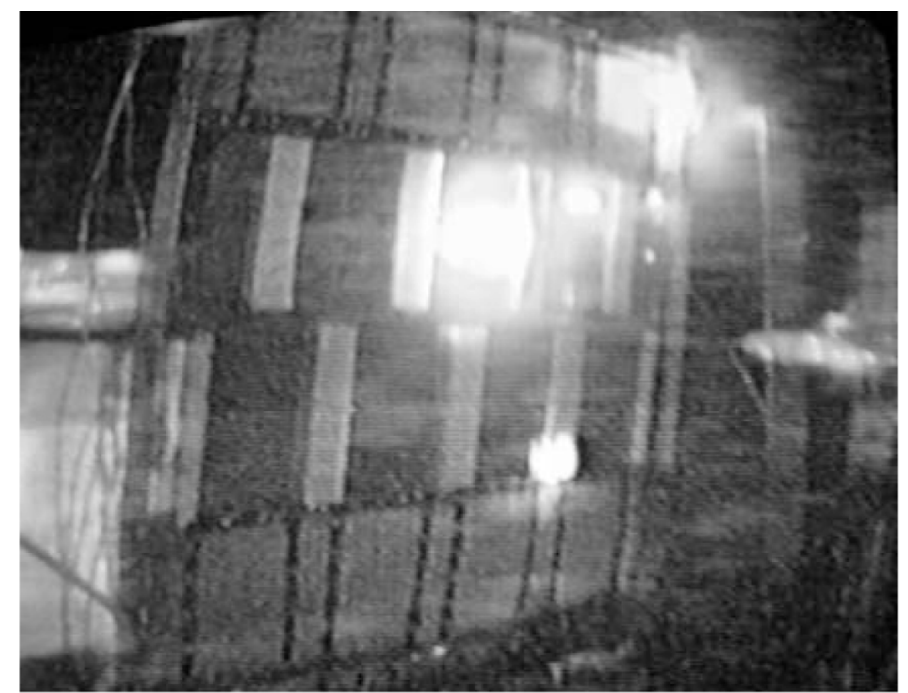

Figure 10.-Snapshot of Emcore AR coated array showing multiple discharges recorded under $-9.5 \mathrm{kV}$ bias and irradiated with $10 \mathrm{keV}$ beam energy and $5 \mathrm{nA} / \mathrm{cm}^{2}$ beam current density.
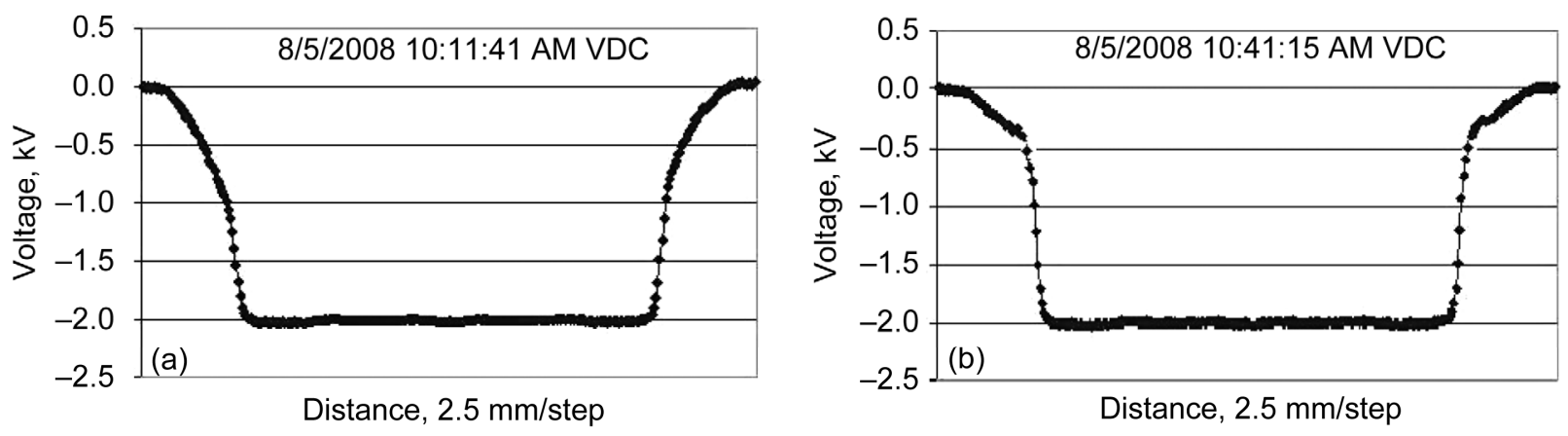

Figure 11.-(a) Surface potential scan with array biased at $-2 \mathrm{kV}$. (b) surface potential scan after irradiating biased array with e-beam energy of $2.5 \mathrm{keV}$ and beam flux of $2 \mathrm{nA} / \mathrm{cm}^{2}$.

\section{Spectrolab AR-ITO GEO Results}

All four strings were biased at $-2 \mathrm{kV}$ potential, and TREK probe scan was performed across the surface of the array. Array surface was next irradiated with e-beam energy of $2.5 \mathrm{keV}$ with an e-beam current flux of $2 \mathrm{nA} / \mathrm{cm}^{2}$. No arcs occurred in the $20 \mathrm{~min}$ allotted time interval. Surface potential scan demonstrated that the ITO layer effectively prevented differential charging (Fig. 11). Beam Current density was increased to $5 \mathrm{nA} / \mathrm{cm}^{2}$ and no arcing occurred at the $-2 \mathrm{kV}$ bias level. Bias voltage was then increased to $-3 \mathrm{kV}$ and exposed to e-beam and irradiated for 15 min with beam energy at $3.5 \mathrm{keV}$ and an e-beam flux of $5 \mathrm{nA} / \mathrm{cm}^{2}$. One arc occurred at dielectric and conductor junction located at the bottom right corner on the bus bar. Continued irradiation of sample for another 15 min using the same beam parameters showed that no arcs occurred and an electrostatic probe scan demonstrated the absence of differential charging of array surfaces. Finally, the array bias and beam energy was increased to $-5 \mathrm{kV}$ and $5.5 \mathrm{keV}$, respectively, using a current beam flux $2 \mathrm{nA} / \mathrm{cm}^{2}$. No arcs were found during $15 \mathrm{~min}$ exposure time. Increasing current flux to $5 \mathrm{nA} / \mathrm{cm}^{2}$ resulted in multiple discharges appeared to originate on the insulated cable leads at the upper left side of the snapshot (Fig. 12). Arcs also appeared on the non-flight like dielectric and conductor junctions located at the top of the array in Figure 12. Sample 


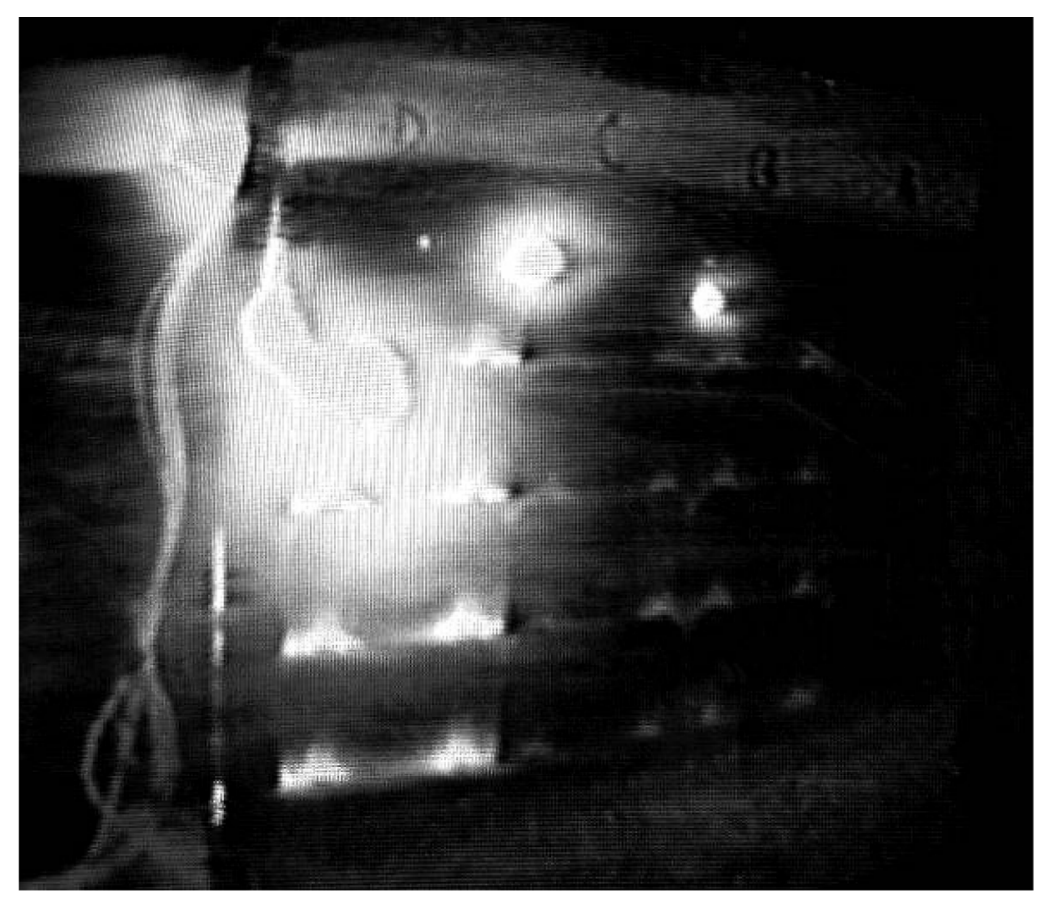

Figure 12.-Multiple discharges at bias potential $-5 \mathrm{kV}$, beam energy $5.5 \mathrm{keV}$, and beam current flux of $5 \mathrm{nA} / \mathrm{cm}^{2}$. The discharges are located on the cable leads.

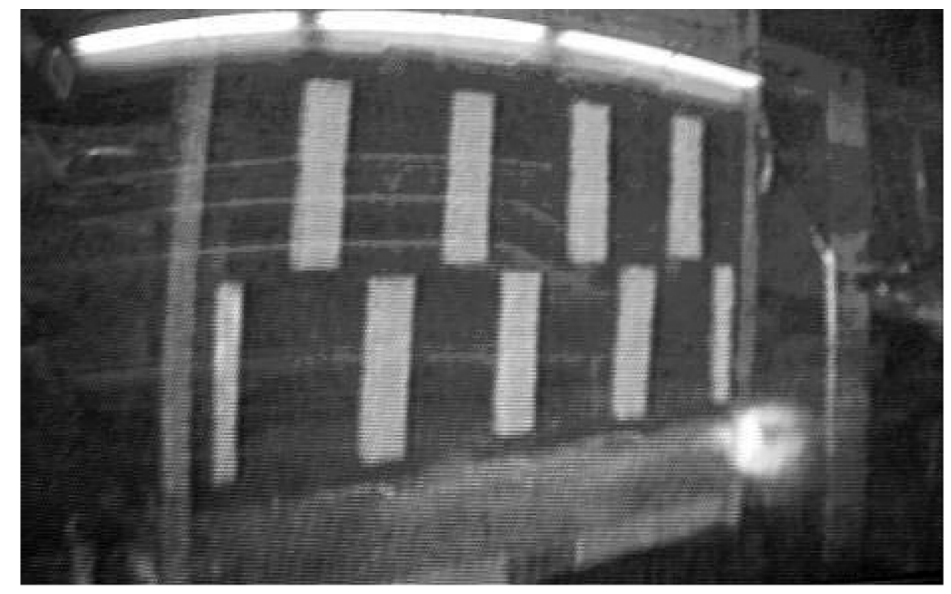

Figure 13.-Example of an arc discharge on the backside of the Spectrolab AR-ITO coated array. Arc was initiated at $-2 \mathrm{kV}$ bias and irradiated with $2.5 \mathrm{keV}$ energy using a $5 \mathrm{nA} / \mathrm{cm}^{2}$ current flux. Note: bright curved horizontal strips at the top of the screen are due to reflections from the lab's florescent lighting fixtures.

The chamber was opened and the array was mounted with the backside facing the electron guns. When testing resumed the backside of the array was biased at $-2 \mathrm{kV}$ and irradiated at beam energy of $2.5 \mathrm{keV}$ and beam current flux of $5 \mathrm{nA} / \mathrm{cm}^{2}$ in a 35-min test. Four arcs were registered on back of the array. The bias level was then increased to $-3 \mathrm{kV}$ and irradiated with a $3.5 \mathrm{keV}$ beam having a beam current flux of $5 \mathrm{nA} / \mathrm{cm}^{2}$ which resulted in four more arc discharges being registered. One example arc on the backside of the array is shown in Figure 13. As a result the backside of the Spectrolab AR-ITO array failed to pass the Stage 2 GEO tests. 


\section{Spectrolab AR GEO Results}

Output leads of all the four strings of the Spectrolab AR array was connected to the negative terminal of the high voltage power supply through the R-C network (Fig. 3). All four array strings were biased at $-2 \mathrm{kV}$ and a surface potential scan was performed before irradiating the array coupons (Fig. 14(a)). The array was then irradiated with $2.8 \mathrm{keV}$ and $1 \mathrm{nA} / \mathrm{cm}^{2}$ beam. First arc occurred on the top right corner of array string $\mathrm{U} 1$ and a second arc occurred at the same site after 2 min of irradiation. A third arc was recorded at the same position as the first two arcs some 7 min later. Beam current was increased to $3 \mathrm{nA} / \mathrm{cm}^{2}$. One arc was registered on the bus bar at the top of string U3. After total of 10 min under irradiation, an electrostatic probe scan indicated differential charging of approximately $800 \mathrm{~V}$ (Fig. 14(b)).

One arc occurred at the top right corner of the array. The e-beam flux was increased to $5 \mathrm{nA} / \mathrm{cm}^{2}$ and a second arc was triggered at the same location. The vacuum chamber was opened and both bus bars were covered with Kapton tape. The sample was reinstalled in the chamber and allowed to pump down to the base operating pressure. Testing resumed by biasing the array at $-2 \mathrm{kV}$ and irradiated with a beam energy of $2.8 \mathrm{keV}$ and e-beam current flux of $5 \mathrm{nA} / \mathrm{cm}^{2}$. An arc discharge was initiated between cells 1 and 2 on string U1 after 7 min under irradiation. The bias voltage, beam energy and current flux was increased to $-3 \mathrm{kV}, 3.6 \mathrm{keV}$, and $2 \mathrm{nA} / \mathrm{cm}^{2}$ and another arc was registered at the same location (top right corner of string U1) as before after $3 \mathrm{~min}$ of e-beam exposure. Increasing the e-beam current flux to $5 \mathrm{nA} / \mathrm{cm}^{2}$ resulted in four more arcs. Figure 15 shows a plot of current pulse recorded for the fourth arc discharge. As a result the front side of the Spectrolab AR coated array failed to pass the Stage 2-GEO tests.
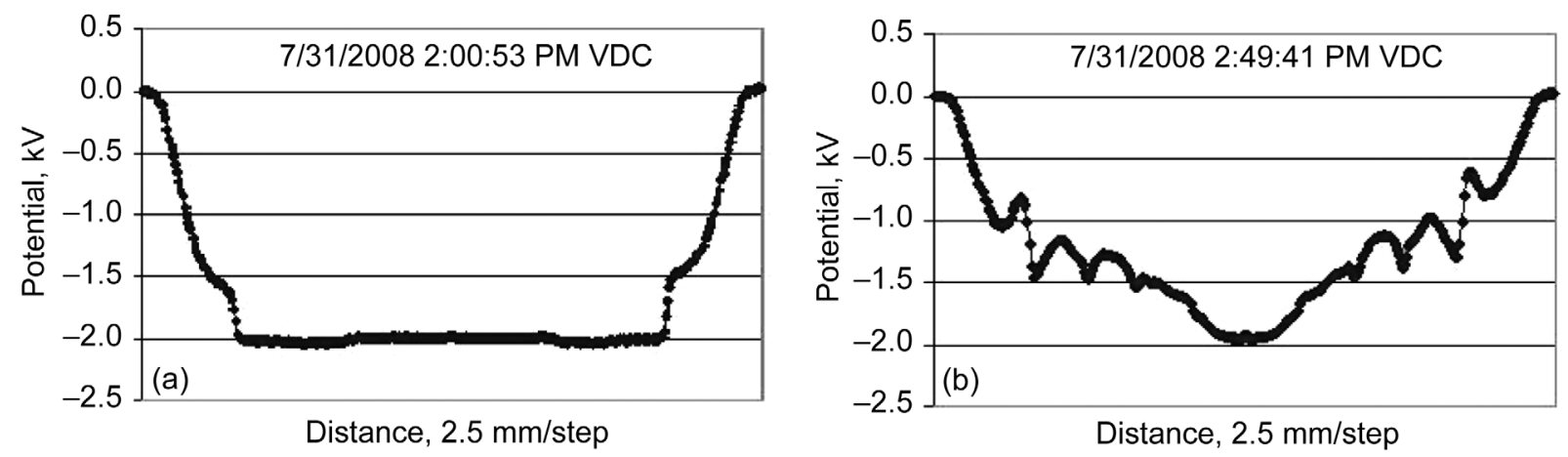

Figure 14.-(a) Surface potential scan shows array coupons biased at a potential of $-2 \mathrm{kV}$. (b) After ten min of irradiation with beam energy of $2.8 \mathrm{keV}$ and beam flux $3 \mathrm{nA} / \mathrm{cm}^{2}$.

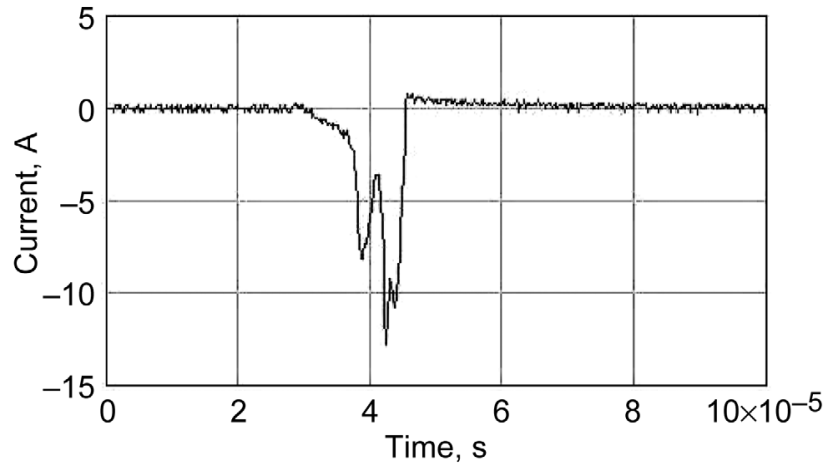

Figure 15.-Current pulse registered at $-3 \mathrm{kV}$ bias, beam energy $3.6 \mathrm{keV}$ and current flux of $5 \mathrm{nA} / \mathrm{cm}^{2}$. 
The chamber was opened and the Spectrolab AR coated array was pointed with the backside of the array facing the two electron guns. Arc discharges began to be registered at a bias voltage set to $-3 \mathrm{kV}$ and when subsequently exposed to e-beam irradiation using beam energy of $3.6 \mathrm{keV}$ and a current density of $2 \mathrm{nA} / \mathrm{cm}^{2}$. A snapshot taken from the video record of an arc discharge on the backside of the array is shown in Figure 16. Beam current flux was next increased to $5 \mathrm{nA} / \mathrm{cm}^{2}$, at the same energy and array bias and an another arc discharge was initiated on the backside of the array. As a result the backside of the Spectrolab AR array sample also failed to pass Stage 2-GEO tests. A summary of front and backside Stage 2 GEO tests results for all Emcore and Spectrolab arrays tested is given in Table 4.

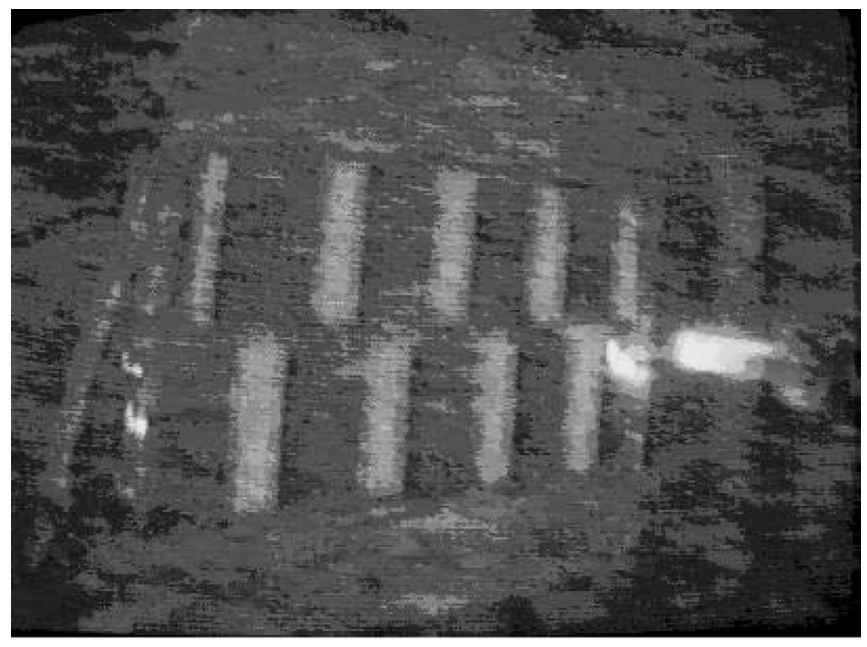

Figure 16.-An example of an arc discharge on backside of the Spectrolab AR coated array sample. Discharge recorded using a bias potential of $-3 \mathrm{kV}$ under e-beam irradiation of $3.6 \mathrm{keV}$ and $2 \mathrm{nA} / \mathrm{cm}^{2}$.

TABLE 4.-SUMMARY OF STAGE 2-GEO TESTS FOR FRONT SIDE AND BACKSIDE OF ALL FOUR EMCORE AND SPECTROLAB ULTRAFLEX ARRAY SAMPLE COUPONS

\begin{tabular}{|c|c|c|c|c|}
\hline Coupon & $\begin{array}{c}\text { Arcing at or below most negative } \\
\text { bias and e-beam charging } \\
\text { parameters tested? } \\
\text { Yes/no } \\
\end{array}$ & $\begin{array}{c}\text { Any arcing margin? } \\
\text { Yes/no }\end{array}$ & $\begin{array}{l}\text { Successful } \\
\text { test? }\end{array}$ & Comments \\
\hline $\begin{array}{l}\text { Emcore Thin BTJM AR-ITO } \\
\text { Front to e-beam }\end{array}$ & $\begin{array}{l}\text { No (up to }-3 \mathrm{kV}, 3.5 \mathrm{keV} \text {, } \\
7 \mathrm{nA} / \mathrm{cm}^{2}, 0 \mathrm{~V} \text { differential } \\
\text { charging) } \\
\text { Not tested }\end{array}$ & 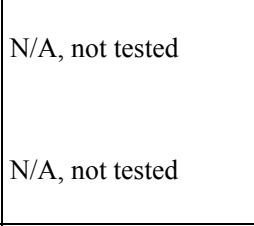 & $x^{2}$ & $\begin{array}{l}\text { Coupon does have ITO on the covers as } \\
\text { proven by the lack of differential charging (tek } \\
\text { probe data) under e-beam exposure. Arcing } \\
\text { did occur on non-flight design flat cabling at } \\
-1.1 \mathrm{kV} \text { bias, } 1 \mathrm{nA} / \mathrm{cm}^{2}, 2 \mathrm{keV} \text { e-beam. These } \\
\sim 10 \text {-A arcs degraded cell IV performance. }\end{array}$ \\
\hline $\begin{array}{l}\text { Emcore Thin BTJM AR } \\
\text { Front to e-beam }\end{array}$ & $\begin{array}{l}\text { Yes (at }-3 \mathrm{kV}, 3.5 \mathrm{keV}, 2 \mathrm{nA} / \mathrm{cm}^{2} \text {, } \\
1.5 \mathrm{kV} \text { differential) } \\
\text { No (up to }-5 \mathrm{kV}, 5.7 \mathrm{keV} \\
5 \mathrm{nA} / \mathrm{cm}^{2} \text { ) }\end{array}$ & $\begin{array}{l}\text { Yes (arcs at next test } \\
\text { point of }-9.5 \mathrm{kV} \\
\left.10 \mathrm{keV}, 5 \mathrm{nA} / \mathrm{cm}^{2}\right)\end{array}$ & Unsuccessful & $\begin{array}{l}\text { Coupon does not have ITO on the covers as } \\
\text { proven by the large differential charging (tek } \\
\text { probe data) under e-beam exposure. Arcing } \\
\text { did occur on non-flight design flat cabling at } \\
-2 \mathrm{kV} \text { bias, } 5 \mathrm{nA} / \mathrm{cm}^{2}, 2.8 \mathrm{keV} \text { e-beam and } \\
1.2 \mathrm{kV} \text { differential charging. These } \sim 10 \text {-A arcs } \\
\text { degraded cell IV performance. }\end{array}$ \\
\hline $\begin{array}{l}\text { Spectrolab Thin UTJ AR } \\
\text { Front to e-beam }\end{array}$ & $\begin{array}{l}\text { Yes }\left(-2 \mathrm{kV}, 2.8 \mathrm{keV}, 1 \mathrm{nA} / \mathrm{cm}^{2}\right. \\
0.8 \mathrm{kV} \text { differential }) \\
\text { Yes }\left(-3 \mathrm{kV}, 3.6 \mathrm{keV}, 2 \mathrm{nA} / \mathrm{cm}^{2}\right)\end{array}$ & N/A, not tested & Unsuccessful & $\begin{array}{l}\text { Coupon arced at string terminal pad and } \\
\text { connection point with round wire cabling. Cell } \\
\text { to cell arcs occurred at }-2 \mathrm{kV}, 2.8 \mathrm{keV} \text { and } \\
5 \mathrm{nA} / \mathrm{cm}^{2} \text { resulting in } 1.3 \mathrm{kV} \text { differential bias. }\end{array}$ \\
\hline $\begin{array}{l}\text { Spectrolab Thin UTJ AR-ITO } \\
\text { Front to e-beam }\end{array}$ & $\begin{array}{l}\text { No (up to }-5 \mathrm{kV}, 5.5 \mathrm{keV} \text {, and } \\
2 \mathrm{nA} / \mathrm{cm}^{2}, 0-\mathrm{V} \text { differential) } \\
\text { Yes }\left(-2 \mathrm{kV}, 2.5 \mathrm{keV}, 5 \mathrm{nA} / \mathrm{cm}^{2}\right)\end{array}$ & $\begin{array}{l}\text { N/A, not tested } \\
\text { N/A, not tested }\end{array}$ & Unsuccessful & $\begin{array}{l}\text { Coupon arced at string terminal pad and } \\
\text { connection point with round wire cabling } \\
\text { under conditions of }-3 \mathrm{kV} \text { bias, } 3.5 \mathrm{keV} \text {, } \\
2 \mathrm{nA} / \mathrm{cm}^{2} \text { e-beam. }\end{array}$ \\
\hline
\end{tabular}




\section{Conclusions}

Generally speaking, all Emcore and Spectrolab UltraFlex, AR and AR-ITO coated, array designs successfully passed the Stage1 LEO tests results, showing no signs of arcing down to $-240 \mathrm{~V}$ array bias. The Emcore and Spectrolab ITO coated cells and interconnect regions appear to be well designed for operating ESD free in LEO plasma environment. Furthermore, the reported string currents measurements are low (approx. $4 \mathrm{~mA}$ ) even for the Spectrolab ITO coated array sample which collects slightly more current than the Emcore array, so that parasitic current loss should not be an issue for either of these arrays. The front side of the ITO coated CIC array samples from Emcore and Spectrolab also appear to be suitable for use in the GEO charging environments because the ITO coated array cells did not arc on the front side flight like regions of the array. (Surface potential scans after e-beam irradiation show that the ITO layer effectively bleeds off the charge). Emcore and Spectrolab CIC coupons layered with ITO are extremely promising in mitigating differential charging effects $n$ the front side of the array, but still have a number of basic technical engineering problems that needs to be overcome before they can be safely used for operations in the GEO and Lunar mission environments. For example, minor "flight wing" design changes are needed to eliminate differential charging effects on the Teflon mask and the Tedlar dielectric coatings in the non-flight like areas of the array. String termination pads and wiring need to be redesigned to eliminate arcs on non flight like array regions on the front side of the array. Backside of the Vectran gore mesh also needs to have additional insulation added to prevent arcing on the backside of the array. The current test results have provided much valuable information concerning the expected complex charging behavior and survivability of the Orion CEV UltraFlex array design in both the LEO and GEO mission environments. In conclusion, a single UltraFlex photovoltaic array can be designed to satisfactorily cope with extended operations in the in low earth orbit and geosynchronous mission environments provided technical problems are properly addressed.

\section{References}

1. Hillard, G., Vayner, B., Galofaro, J., Snyder, D., Dever, J.A., and Miller, S.K., "Preliminary Assessment of Environmental Interactions for the Orion Solar Arrays," NASA/GRC Internal Document (not Published), June 15, 2007.

2. Ferguson, D., Hillard, G., Snyder, D., and Grier, N., "The Inception of Snapover on Arrays: A Visualization Technique," AIAA-98-1045, 36th AIAA Aerospace Sciences Meeting and Exhibit, Reno, NV, Jan. 12-15, 1998, pp. 1-8.

3. Galofaro, J.T., Vayner, B.V., Degroot, W.A., Ferguson, D.C, Thomson, C.D., Dennison, J.R., and Davies, R.E., "Inception of Snapover and Gas Induced Glow Discharges," NASA/TM-2000209645, Jan., 2000.

4. Caven, P., Coffey, V., Schneider, T., Vaughn, J., Wright, K., and Minow, J., "Survey of International Space Station Charging Events," AIAA Paper 2009-0119, Jan. 2009.

5. Carruth, M.R. et al., "ISS and Space Environment Interactions Without Operating Plasma Contactor," AIAA Paper 2001-0401, Jan. 2001.

6. T. Schneider et al., "Minimum Arc Threshold Voltage Experiments on Extravehicular Mobility Unit Samples," AIAA Paper 2002-1040, Jan. 2002.

7. Purvis, C.K., Garrett, H.B., Whittlesey, A.C., and Stevens, N.J., "Design Guidelines for Assessing and Controlling Spacecraft Charging Effects," NASA TP-2361, 1984. 


\begin{tabular}{|c|c|c|}
\hline \multicolumn{2}{|c|}{ REPORT DOCUMENTATION PAGE } & $\begin{array}{l}\text { Form Approved } \\
\text { OMB No. 0704-0188 }\end{array}$ \\
\hline \multicolumn{3}{|c|}{$\begin{array}{l}\text { The public reporting burden for this collection of information is estimated to average } 1 \text { hour per response, including the time for reviewing instructions, searching existing data sources, gathering and maintaining the } \\
\text { data needed, and completing and reviewing the collection of information. Send comments regarding this burden estimate or any other aspect of this collection of information, including suggestions for reducing this } \\
\text { burden, to Department of Defense, Washington Headquarters Services, Directorate for Information Operations and Reports (070404-0188), , } 215 \text { Jefferson Davis Highway, Suite } 1204 \text {, Arlington, VA } 22202-4302 \text {. } \\
\text { Respondents should be aware that notwithstanding any other provision of law, no person shall be subject to any penalty for failing to comply with a collection of information if it does not display a currently valid OMB } \\
\text { control number. } \\
\text { PLEASE DO NOT RETURN YOUR FORM TO THE ABOVE ADDRESS. }\end{array}$} \\
\hline $\begin{array}{l}\text { 1. REPORT DATE (DD-MM-YYYY) } \\
01-09-2011\end{array}$ & $\begin{array}{l}\text { 2. REPORT TYPE } \\
\text { Technical Memorandum }\end{array}$ & 3. DATES COVERED (From - To) \\
\hline \multirow{3}{*}{\multicolumn{2}{|c|}{$\begin{array}{l}\text { 4. TITLE AND SUBTITLE } \\
\text { Experimental Tests of UltraFlex Array Designs in Low Earth Orbital and Geosynchronous } \\
\text { Charging Environments }\end{array}$}} & 5a. CONTRACT NUMBER \\
\hline & & 5b. GRANT NUMBER \\
\hline & & 5c. PROGRAM ELEMENT NUMBER \\
\hline \multirow{3}{*}{\multicolumn{2}{|c|}{$\begin{array}{l}\text { 6. AUTHOR(S) } \\
\text { Galofaro, Joel, T.; Vayner, Boris, V.; Hillard, Grover, B. }\end{array}$}} & 5d. PROJECT NUMBER \\
\hline & & 5e. TASK NUMBER \\
\hline & & $\begin{array}{l}\text { 5f. WORK UNIT NUMBER } \\
\text { WBS 644423.06.32.03.05.03 }\end{array}$ \\
\hline \multicolumn{2}{|c|}{$\begin{array}{l}\text { 7. PERFORMING ORGANIZATION NAME(S) AND ADDRESS(ES) } \\
\text { National Aeronautics and Space Administration } \\
\text { John H. Glenn Research Center at Lewis Field } \\
\text { Cleveland, Ohio 44135-3191 }\end{array}$} & $\begin{array}{l}\text { 8. PERFORMING ORGANIZATION } \\
\text { REPORT NUMBER } \\
\text { E-17328 }\end{array}$ \\
\hline \multirow{2}{*}{\multicolumn{2}{|c|}{$\begin{array}{l}\text { 9. SPONSORING/MONITORING AGENCY NAME(S) AND ADDRESS(ES) } \\
\text { National Aeronautics and Space Administration } \\
\text { Washington, DC 20546-0001 }\end{array}$}} & $\begin{array}{l}\text { 10. SPONSORING/MONITOR'S } \\
\text { ACRONYM(S) } \\
\text { NASA }\end{array}$ \\
\hline & & $\begin{array}{l}\text { 11. SPONSORING/MONITORING } \\
\text { REPORT NUMBER } \\
\text { NASA/TM-2011-216752 }\end{array}$ \\
\hline \multicolumn{3}{|c|}{$\begin{array}{l}\text { 12. DISTRIBUTION/AVAILABILITY STATEMENT } \\
\text { Unclassified-Unlimited } \\
\text { Subject Category: } 18 \\
\text { Available electronically at http://www.sti.nasa.gov } \\
\text { This publication is available from the NASA Center for AeroSpace Information, 443-757-5802 }\end{array}$} \\
\hline
\end{tabular}

\section{SUPPLEMENTARY NOTES}

\section{ABSTRACT}

The present ground based investigations give the first definitive look describing the expected on-orbit charging behavior of Orion UltraFlex array coupons in the Low Earth Orbital and Geosynchronous Environments. Furthermore, it is important to note that the LEO charging environment also applies to the International Space Station as well as to the lunar mission charging environments. The GEO charging environment includes the bounding case for all lunar orbital and lunar surface mission environments. The UltraFlex thin film photovoltaic array technology has been targeted to become the sole power system for life support and on-orbit power for the manned Aires Crew Exploration Vehicle. It is therefore, crucial to gain an understanding of the complex charging behavior to answer some of the basic performance and survivability issues in an attempt to ascertain that a single UltraFlex array design will be able to cope with the projected worst case LEO and GEO charging environments. Testing was limited to four array coupons, two coupons each from two different array manufactures, Emcore and Spectrolab. The layout of each array design is identical and varies only in the actual cell technology used. The individual array cells from each manufacturer have an antireflection layered coating and come in two different varieties either uncoated (only AR coating) or coated with a thin conducting ITO layer. The LEO Plasma tests revealed that all four coupons passed the arc threshold $-120 \mathrm{~V}$ bias tests. GEO electron gun charging tests revealed that only front side area of ITO coated coupons passed tests. Only the Emcore AR array passed backside Stage 2 GEO Tests.

15. SUBJECT TERMS

Orion; Photovoltaic (PV) array

\begin{tabular}{|c|c|c|c|c|c|}
\hline \multicolumn{3}{|c|}{ 16. SECURITY CLASSIFICATION OF: } & \multirow{2}{*}{$\begin{array}{l}\text { 17. LIMITATION OF } \\
\text { ABSTRACT } \\
\text { UU }\end{array}$} & \multirow{2}{*}{$\begin{array}{l}\text { 18. NUMBER } \\
\text { OF } \\
\text { PAGES } \\
22\end{array}$} & \multirow{2}{*}{$\begin{array}{l}\text { 19a. NAME OF RESPONSIBLE PERSON } \\
\text { STI Help Desk (email:help@sti.nasa.gov) } \\
\text { 19b. TELEPHONE NUMBER (include area code) } \\
\text { 443-757-5802 }\end{array}$} \\
\hline $\begin{array}{l}\text { a. REPORT } \\
U\end{array}$ & $\begin{array}{l}\text { b. ABSTRACT } \\
\text { U }\end{array}$ & $\begin{array}{l}\text { c. THIS } \\
\text { PAGE } \\
\text { U }\end{array}$ & & & \\
\hline
\end{tabular}



